\title{
Knowledge, attitudes, and practices towards COVID- 19 pandemic among residents of Jharkhand state, India: An online survey
}

\section{Arpita Rai}

Rajendra Institute of Medical Sciences

Nishant Nishant ( $\nabla$ docnishantmehta@gmail.com )

Rajendra Institute of Medical Sciences

\section{Singh}

All India Institute of Medical Sciences, Bathinda

\section{Nitin Kulkarni}

Ministry of Health and Family Welfare, Government of Jharkhand

\section{Shailesh Chaurasia}

Ministry of Health and Family Welfare, Government of Jharkhand

\section{Pathak}

State Non Communicable Division, Jharkhand

\section{Research Article}

Keywords: knowledge, attitudes, practice, surveys and questionnaires, corona virus, COVID-19

Posted Date: December 1st, 2020

DOI: https://doi.org/10.21203/rs.3.rs-116495/v1

License: (1) This work is licensed under a Creative Commons Attribution 4.0 International License. Read Full License

Version of Record: A version of this preprint was published at Journal of Pharmaceutical Research International on November 29th, 2021. See the published version at https://doi.org/10.9734/jpri/2021/v33i52A33573. 
Title: Knowledge, attitudes, and practices towards COVID-19 pandemic among residents of Jharkhand state, India: An online survey

Authors:

1. Arpita Rai

Associate Professor,

Dental Institute, Rajendra Institute of Medical Sciences, Ranchi, Jharkhand, India, 834009

E mail id: arpita.dirims@gmail.com

Mobile Number: 9871743893

2. Nishant Nishant

(Corresponding author)

Assistant Professor,

Dental Institute, Rajendra Institute of Medical Sciences, Ranchi, Jharkhand, India, 834009

E mail id: docnishantmehta@gmail.com

Mobile Number: 8826370234

3. D.K. Singh

Director,

All India Institute of Medical Sciences, Bathinda, Punjab, India

Ex Director, Rajendra Institute of Medical Sciences, Ranchi, Jharkhand, India, 834009

E mail id: director-rims@jharkhandmail.gov.in

Mobile Number: 9415201218

4. Nitin Madan Kulkarni

Principal Secretary

Ministry of Health, Family Welfare and Medical Education, Government of Jharkhand, 834010

E mail id: nitinkulkarni.ias@gmail.com

Mobile number: 09431121011

\section{Shailesh Kumar Chaurasia}

Mission Director (NHM)

Department of Health \& Family Welfare, Government of Jharkhand

State RCH office, G. V. I. Campus, Namkum, Ranchi, Jharkhand, India, 834009

E mail id: mdnrhmjharkhand@ gmail.com

Mobile number: 09436891080

\section{LR Pathak}

State Nodal Officer,

State NCD Cell,

RCH Campus, Tata Rd.Namkum, Ranchi, Jharkhand, India, 834009

E-mail - ncdjharkhand@gmail.com

Mobile number: 9472762757 


\begin{abstract}
:
Background: People's adherence to control measures is imperative in the fight against COVID19. The present study was done to evaluate knowledge, attitudes, and practices towards COVID19 among residents of Jharkhand and to assist government in deciding further course of action during the COVID-19 outbreak. Methods: This study was an online cross sectional survey. The link to the questionnaire was displayed on the official website of Rajendra Institute of Medical Sciences, Ranchi, Government of Jharkhand, National Health Mission, Jharkhand, official website of all districts under Jharkhand state administration, Integrated Disease Surveillance Programme and Information \& Public Relations department. Participation of residents in the survey was also extensively propagated using mass media mainly local television networks, radio channel and newspapers. Results: A total of 4683 responses were received from all districts of Jharkhand. Majority of the participants were young adults (47.5\%) and number of male participants was more than the females (81.4\%). Mean correct knowledge score for participants of this study was 10.73+2.2 (maximum attainable score was 14) while mean practice score for the participants was 4.5+0.69 (maximum attainable score was 5). Knowledge score of the participants was significantly associated with their age, education status and economic class $(\mathrm{p}<0.05)$. The participants largely held an optimistic attitude and healthy practices towards COVID-19. Conclusions: Participants had positive attitude but were also logically worried and uncertain about near future. Adequate knowledge of participants was visible in the practices of residents. There was however a gap across age groups, gender, literacy and income levels which should be addressed in future campaigns.
\end{abstract}

Key words: knowledge, attitudes, practice, surveys and questionnaires, corona virus, COVID-19 


\section{Background:}

The novel coronavirus disease 2019 (“COVID-19”) has grown into pandemic proportions making it one of the most serious infectious diseases affecting mankind. [1]. The disease carry a spectrum of complications in moderate and advanced stages including bronchitis, pneumonia, severe acute respiratory syndrome (SARS) and sepsis and multiorgan involvement $[2,3]$. Keeping in mind the rapid spread of disease, WHO took an early stance and declared it as a public health emergency of international concern (PHEIC) on 30 January 2020, [4]. The first week of March saw an overwhelming steep rise in the number of new cases reported worldwide compelling WHO to declare it as a pandemic. As of $27^{\text {th }}$ September 2020 (1:08pm CEST) 212 Countries and Territories globally have reported a total of 32,730,945 confirmed cases of the coronavirus, with a death toll of 991,224 [5]. In India, the COVID-19 has already spread to almost all the states and union territories with 9,62,640 active cases of COVID-19 and 95542 deaths reported so far [6]. A distressing many folds spike of initial levels has been reported in the number of COVID-19 cases rising across the country in first few days of May [7].

Jharkhand, ("The land of forest") is a state in eastern India having 5 administrative divisions and 24 districts [8]. In the Indian context, it is the $15^{\text {th }}$ largest state by area, and the $14^{\text {th }}$ largest by population [9].Jharkhand is one of the least developed states of the country based on the index of (under) development proposed by Committee for Evolving a Composite Development Index of States in 2013 [10]. It ranks $27^{\text {th }}$ out of 28 states in the poverty rate (2013), $33^{\text {rd }}$ out of 36 states and union territories in terms of literacy rates (2011) and $16^{\text {th }}$ out of 25 states according to unemployment rate (2017-18) [11-13]. However, in the initial stages of COVID-19 pandemic, the state of Jharkhand reported some of the lowest infection rates. As of now out of 66797 cases which have been reported so far, 12433 are active and 679 patients have lost their lives due to COVID-19 [6].

There is virtual lack of any treatment or vaccine specifically approved for COVID-19. The most important factor in preventing the spread of the virus locally is to empower the citizens with the right information, busting myths and misconceptions and taking precautions as per the advisories being issued by Ministry of Health \& Family Welfare [14]. It is imperative to measure the extent of a known situation about COVID-19 among Jharkhand residents, assess the effectiveness of government policies to contain COVID-19, establish the reference value for use in future assessments, design preventive strategies and interventions and make evidence-based adjustments as the outbreak evolves based on the felt need of the population. Hence

\section{Methodology:}

\section{Aim, design and study setting:}

This descriptive, cross sectional online study was planned to evaluate knowledge, attitudes, and practices (KAP) towards COVID-19 among residents of Jharkhand state and to assist state government in deciding further course of action during the COVID-19 outbreak. This study was conducted in the month of April to August 2020. The study group comprised of the individuals above 18 years of age, residing in Jharkhand state and having an access to the internet. Diagnosed COVID-19 cases and quarantined individuals were excluded from the study.

Permission and approvals: Permission to carry out this study was obtained from i)The Principal Secretary, Department of Health, Medical Education \& Family Welfare, Government of Jharkhand ii) Director, Rajendra Institute of Medical Sciences, Government of Jharkhand iii) Mission Director, National Health Mission, 
Government of Jharkhand iv) Nodal Officer, Non Communicable Disease, Government of Jharkhand. The proposal was approved by Research and Project Committee and Institute Ethics Committee, Rajendra Institute of Medical Sciences, Ranchi, Jharkhand. Participation in the survey was purely voluntary. The survey link mentioned implied consent from the survey participants i.e. those clicking the link and filling up the forms were considered to have given the consent.

\section{Sample size estimation:}

It was done using epi-info software (version3.01) [15]. Sample size estimation was based on a similar study done among Chinese residents to assess their knowledge, attitudes, and practices towards COVID-19 [16]. Based on the reported $90 \%$ prevalence ofcorrect responses in the study and allowable error of $5 \%$, the required sample size for the study came out to be 139. To compensate for the difference of the awareness levels of the residents in the two regions, a design effect of 1.5 was applied to make the final sample size to be 208 .

\section{Sampling methodology:}

It was an online survey with voluntary participation of the state residents. However, the purpose of the study, eligibility criteria and the anonymity and confidentiality clause were clearly highlighted for respondents before filling up of the questionnaire. The link to the survey questionnaire in both Hindi and English was displayed on the official website of all districts of the state along with their e-portals like Facebook, Twitter, WhatsApp. It was also available on the official website of Rajendra Institute of Medical Sciences, National Health Mission (NHM, Jharkhand), all online portals under NHM, Jharkhand, Integrated Disease Surveillance Programme, and was propagated extensively by the Information \& Public Relations Department. Survey information with link to questionnaire was also promoted through local television networks, radio channels and newspapers so that maximum number of participations could be achieved.

Survey tool: A self-structured questionnaire was used to record the responses of the candidates. A thorough review of the various studies already conducted in various parts of the world through structured, semi-structured, or nonstructured interview schedule or self-administered questionnaires were taken into account for item selection of this tool [16-19]. Since data on COVID-19 is scant, we also considered the questionnaires developed for the MERS and H1N1 [20,21]. To generate a comprehensive set of items relevant to Indian scenario we used information available on MyGov \#IndiaFightsCorona COVID-19 dashboard of Ministry of Health and Family Welfare, Government of India [6]. The questionnaire consisted of four sections; $1^{\text {st }}$ sections include questions on demographic profile of the candidate in both closed and open-ended format. $2^{\text {nd }}$ section consists of fourteen closed ended questions to assess participant's knowledge under three domains; clinical aspects (4 questions), spread (4 questions) and prevention \& control of COVID-19 (6 questions). $3^{\text {rd }}$ section includes set of five closed ended questions to assess participant's attitude towards COVID-19. $4^{\text {th }}$ sections included set of 5 closed ended and 1 open ended questions to assess participant's practices towards COVID-19. In the study we have kept the threshold value for calculating correct rates of knowledge and practices at the 50\% value of the maximum possible score. Threshold value for classifying knowledge and practices to be adequate were 7 for knowledge and 3 for practice. One question in the practices, "Do you verify news regarding COVID-19 before forwarding on social media" was not used in the calculation of practice score of the participants. This method is commonly used method of determining the threshold values in the absence 
of any standardized tool. The threshold values thus obtained to classify knowledge and practice scores were also found to be of relevance to epidemiological and public health experts in the state. Content validity of the questionnaire was ensured with the help of ten experts in the field. Final questionnaire in English was translated into Hindi language. Hindi to English back translation was carried out to check the quality of translation. A pilot study was carried out on 25 subjects to check the reliability (Cronbach's alpha) and comprehensibility of the questionnaire. It took a participant approximately 3-5 minutes to complete the questionnaire. The knowledge section of the questionnaire was formulated in form of a quiz with highest attainable score of 14. The participants could view their own scores as well as the correct responses at the end of the submission. This was one as a measure to improve respondent's knowledge about COVID-19. Additionally, the participants were given an option to view others responses so that they could update themselves with the current status of responses in relation to this questionnaire. The final questionnaire version was adapted in the Google Forms and online link for the same was created.

\section{Statistical analysis:}

Data obtained was entered in the Microsoft excel and subjected to statistical analysis using SPSS version 18.0 [22]. Descriptive analysis was done to classify demographic details and responses to KAP questions. Correct responses were given a score 1 and incorrect responses were scored as 0 for assessment of knowledge and practice of the participants. Responses were be added up to calculate the correct knowledge and practice scores of the participants. Participants were classified to be aware/unaware and following good/bad practices as per the threshold value. Mean correct score for knowledge and practices was also calculated. Chi-square test was used to find association between study variables; 1) demographic variables and knowledge \& practices of participants 2) knowledge and practices of the participants.

\section{Results:}

\section{Study participants characteristics}

A total of 4683 responses were received from all the 24 districts of Jharkhand state. Majority of the participants were males $(81.4 \%)$ below 30 years of age. Most of the participants were of the level of graduate or above (81.7\%). A mix of responses was received from different work categories and more than 30 percent of total participants had a monthly income of up to 132 USD. (Table I). Mean correct knowledge score was $10.73 \underline{2} 2.2$. More than $70 \%$ correct response rate was observed for most of the question except regarding usage of appropriate type of sanitizer. Approximately $4 \%$ of the participants confused the symptoms of common flu and gastro-intestinal ailments clinical symptoms of COVID-19 infection. Approximately 29\% respondents were not aware of the ways of spread of COVID-19, more importantly regarding spread from asymptomatic patients. (Table II). Approximately $90 \%$ of the participants were in the view that COVID-19 will finally be controlled in India. However, $27.2 \%$ believed that the virus is going to stay for at least 6 months time period and $21.1 \%$ of them were unsure about the time duration required to contain the virus (Table III). An analysis of the type of fear among those who are worried about COVID-19 revealed that fear of death was the single most common fear among the participants across all the age groups. (Image I). Mean practice score for the participants was $4.5 \pm 0.69$ (Table IV). More than $92 \%$ of the participants followed the lockdown as per the government guidelines and did not go outside of their homes without 
any compelling reason. Around $98 \%$ of the participants did wear mask while going out and but around one third of the participants did not made efforts to avoid touching the eyes, nose, and mouth with their hands (Table IV). A very significant finding from this study is that majority of participants were updating themselves through the authentic information provided by central and state government $(57.2 \%)$ or by using dedicated COVID-19 dashboard \#IndiaFightsCorona by MyGov.in (49.5\%) (Image II). Female participants and those of the higher age groups were more aware regarding COVID-19 ( $<<0.05)$. Education status was significantly associated with the knowledge and practices in relation to COVID-19 ( $\mathrm{p}<0.05)$. Similarly those falling in the higher economic classes were more aware about COVID-19 ( $<<0.05)$ however practices were similar across the all economic strata (Table V). Knowledge of the participants was significantly translated into the practices of the participants. Individuals who were aware in the present scenario also performed good practices in relation to COVID-19 (Table VI).

\section{Discussion}

To the best of our knowledge, this is the first study in India which was done at state wide level to examine the KAP towards COVID-19 among general residents. The area of study is especially important given the impact of disease on the mankind with world leaders quoting the pandemic an important landmark in history of world, dividing the timelines into pre-corona and post-corona period. The study findings shall be utilized by the state government to effectively design future course of action in wake of COVID-19.

In the study we found an overall high correct rate in the knowledge questionnaire, indicating that most respondents are knowledgeable about COVID-19. High correct rate of knowledge in relation to COVID-19 among Jharkhand residents was not unexpected. Jharkhand state was $28^{\text {th }}$ state in the country to report COVID positive patient [23]. The state was reportedly corona free till 31 st March 2020 when the nationwide coronavirus death toll climbed to 32 while the number of cases had spiked to 1251, which is approximately two months after the reporting of 1st case in the country [24]. The transmission rate of COVID-19 in the state is also low when compared to the national average. As of $17^{\text {th }}$ May 2020, there are only 101 active COVID-19 positive cases in the state. Serious situation of the epidemic and the overwhelming news reports on this public health emergency are also responsible for high correct rate of knowledge and good practices. The high level of awareness among study population regarding COVID-19 has been reported from other studies too $[16,19,25]$. However, many areas of concern have been identified based on the survey findings. Still $100 \%$ of the population is not aware of the symptoms related to COVID-19 and days taken to appear the symptoms. It is empirical for everybody to understand basic symptomatology since shorter the time taken to report to a screening centre the lesser will be the spread and the health effects. It is unknown to many that elderly age groups and those with the co-morbidities are more prone of getting infected. Several studies have shown that patients with older age and co-morbidities like hypertension, diabetes, cardiovascular disease and respiratory system disease need careful observation and early intervention to prevent the potential development of severe COVID-19 [26,27]. These groups should especially be reached to make them more responsive towards implementing self-prevention measures. Ways of viral spread and suitable distance to be maintained with other people were not recognized by significant number of the participants. $R$ naught value of the disease is higher than one, implying a faster and rapid spread of disease before it ceases down [28]. Addressing issues related to the spreadibility of disease will help prevent its exponential spread given the highly contagious nature of disease. Still 
one fourth of the participants were unaware of government guidelines on mandatory usage of face masks indicating a gap in framing, implementation and publicizing of the novel laws. Markets are these days floated with various kind of sanitizers with repots coming that many not following specifications required for prevention against COVID-19 [29,30,31] It is imperative for public to understand type of sanitizers to be used so that they do not stay in swag that they are adequately protected after using any sort of sanitizer available in the market.

The majority of the participants also held a hopeful attitude towards the COVID-19 pandemic. Most of them believed that COVID-19 will finally be successfully controlled, and had confidence that India will ultimately get though the situation. This is in synchronization with the results of another study carried out in another region of India where people also held optimistic attitude about the disease [32]. The confident attitude of the Jharkhand residents could be related to the unprecedented COVID-19 control measures such as country-wide lock down, mandatory wearing of masks and banning of pan masala by the state of Jharkhand, sealing of hotspots, developing dedicated COVID-19 hospitals with isolation, quarantine and management facilities for COVID-19 infected and suspected patients, sanitization drives and rigorous contact tracing of which enhance people's confidence in winning the battle against the virus. [33]. Similar to results of another study carried out in China, in our study also respondents feared of death the most among all age groups [34]. The fear among participants to a certain extent is being answered in newer government campaigns that emphasize upon increasing body's immunity so that even if the disease is encountered one may remain asymptomatic and apparently well. Also, gradually with increased understanding of the disease, we have more treatment options and better recovery rates [35,36,37]. Newer campaigns should definitely take into the account social stigmas attached to the disease. For example "Hate Disease but not the Diseased" is already been promoted across COVID-19 campaigns [38].

Sound knowledge and optimistic attitude of the participants was also reflected in their practices in this period $[16,17,18,19]$. But there are concern areas; especially mask hygiene should be emphasized; firstly, wearing a mask for their as well as others safety is important and secondly, that outer surface of mask should never be touched. Also, indigenously developed corona tracker mobile application "AarogyaSetu" is not been used by all. Rigorous emphasis on its utility among masses in terms of daily updates, self-risk assessment and option for applying of epass could prove beneficial. Source of information for more than half of participants was government recommendations or state run online dashboards. It confirms that national and state governments are putting efforts to connect and reach to the people.

Age of the participants did have an impact on the knowledge of participants but the practices did not significantly improved with increasing age. Since, it can be assumed that people of all groups were sensitized and worried in the present scenario so everyone tried to perform good practices. Females out-performed their male counterparts as far as knowledge regarding COVID-19 was tested [16]. However, male participants performed significantly better practices than the females. The possible reason could be that in India, socio-cultural beliefs enable males to go out of home more frequently than females for daily routine chores or employment related work so they keep themselves more equipped and follow healthy hygiene practices more religiously. However, since females get more time to stay at homes and use internet so are more aware than the males. 
At present there are generic awareness campaigns being carried out throughout the country and in the state as well. These campaigns are not been designed keeping in mind the felt needs, current knowledge and practice being performed by the residents. The areas identified with a knowledge lag could be specifically targeted using behavioral change communication techniques. The domains where already acceptable knowledge levels have been reached can only be targeted through sensitization and re-enforcement strategies. The future campaigns should definitely take into account the socio-cultural and economic context into account. Key stakeholders like non government organizations which are active in the region can be involved suitably. Many people believe that corona is going to stay for longer. Hence future information education communication/behavioral change communication campaigns should be more than just awareness raising campaigns government [25,39]. They should also teach people on how to live with corona in times to come. Social taboos related to COVID-19 infection among residents should also be addressed so that people do not avoid visiting COVID screening facilities. Development of standard operating procedures for all job sectors shall help in early resumption of services to ease down financial worries besides preventing spread of corona at the workplaces. [40,41]. Social media was source of information for significant proportion of population. Hence, social media platforms like WhatsApp and Facebook should be utilized for dissemination of authentic updates on COVID-19.

The study was a web based survey of the KAP practices among the residents of Jharkhand state, India. Opinion of considerable population which might not have an access to internet might have been left in the survey. However, the large sample size involved in the study validates the findings to an extent. Responses from all ages, educational \& occupational classes and economic strata have been received with varying proportions that corresponds to their population size. There was possibility of hawthorne effect in this study but clause of anonymity and study being an online survey would have limited the bias. The study also touched the areas related to mental health, economic issues but did not take an elaborated opinion. Hence future studies examining impact of COVID-19 on mental health and economic aspects of individuals can be planned to bring a comprehensive policy or guidelines in relation to pandemic. Health impact of COVID-19 on should be assessed to reorient health care delivery system in the current situation demanding limited mobility of people.

\section{Conclusions:}

The study identified thrust areas for future awareness campaigns. Participants had positive attitude but were also logically worried and uncertain about near future. Adequate knowledge of participants was visible in the practices of residents. There is however a gap across age groups, gender, literacy and income levels which should be addressed in future campaigns

\section{List of abbreviations: Not applicable}

Ethics approval and consent to participate: The proposal was approved by Research and Project Committee and Institute Ethics Committee, Rajendra Institute of Medical Sciences, Ranchi, Jharkhand vide number 12/13/04/2019. Participation in the survey was purely voluntary. Informed consent was obtained from the study participants.

Consent for publication: Not applicable 
Availability of data and materials: Not applicable

Competing interests: The authors declare that they have no competing interests.

Funding: The study received technical, non-financial support for the dissemination of the survey link across government websites; online portals under National Health Mission, official website of all district administrations, Integrated Disease Surveillance Programme and Information \& Public Relations Department.

Authors' contributions: AR carried out designing and literature review. NN was involved in manuscript writing and statistical analysis. DK was involved in conceptualization and designing. NM developed the definition of intellectual content and carried overall reviewing. SK provided technical inputs and carried critical revision. LR was involved in designing the survey tool and providing recent updates on COVID-19 in the Jharkhand state which were utilized in manuscript preparation. All authors took part in research meetings concerning data analysis goals, strategies, challenges and visualization.

Acknowledgements: Not applicable

\section{References:}

1. Mackenzie JS, Smith DW. COVID-19: a novel zoonotic disease caused by a coronavirus from China: what we know and what we don't. Microbiol Aust. 2020 Mar 17:MA20013. doi: 10.1071/MA20013. Epub ahead of print. PMID: 32226946; PMCID: PMC7086482.

2. The Novel Coronavirus Pneumonia Emergency Response Epidemiology Team. The epidemiological characteristics of an outbreak of 2019 novel coronavirus diseases (COVID-19) in China. Chin J Epidemiol. 2020;41:145-51

3. Chen N, Zhou M, Dong X, Qu J, Gong F, Han Y. et al. Epidemiological and clinical characteristics of 99 cases of 2019 novel coronavirus pneumonia in Wuhan, China: a descriptive study. Lancet. 2020;395:50713

4. World Health Organization. Novel coronavirus (COVID-19) situation. Available online: https:// https://experience.arcgis.com/experience/685d0ace521648f8a5beeeee1b9125cd

5. World Health Organization. WHO Official Updates. Coronavirus Disease 2019. Available online: https://covid19.who.int/

6. Government of India. COVID-19 dashboard. Available online: https://www.mygov.in/covid-19/

7. India today. Available on: https://www.indiatoday.in/diu/story/mayhem-in-may-india-rise-covid-19-casessecond-highest-world-1677295-2020-05-12

8. Simple English Wikipedia. List of districts in Jharkhand. Available on: https://simple.wikipedia.org/wiki/List_of_districts_in_Jharkhand

9. Wikipedia. List of states and union territories of India by area. Available on: https://en.wikipedia.org/wiki/List_of_states_and_union_territories_of_India_by_area

10. Report of the committee for evolving a composite development index of states (Raghuram Rajan Panel report). GOVERNMENT OF INDIA. MINISTRY OF FINANCE. SEPTEMBER 2013

11. Wikipedia. List of Indian states and union territories by poverty rate. Available on: https://en.wikipedia.org/wiki/List_of_Indian_states_and_union_territories_by_poverty_rate 
12. Office of the Registrar General \& Census Commissioner, India Ministry of Home Affairs, Government of India. Available on: https://censusindia.gov.in/2011-provresults/data_files/india/Final_PPT_2011_chapter6.pdf

13. Periodic Labour Force Survey (2019-2020)" (PDF). Ministry of Labour and Employment. p. 212. Retrieved $17^{\text {th }}$ May 2020.

14. Ajilore K, Atakiti I, Onyenankey K. College students' knowledge, attitudes and adherence to public service announcements on Ebola in Nigeria: Suggestions for improving future Ebola prevention education programmes. Health Education Journal. 2017;76:648-60.

15. Epi Info ${ }^{\mathrm{TM}}$, Division of Health Informatics \& Surveillance (DHIS), Center for Surveillance, Epidemiology \& Laboratory Services (CSELS)

16. Zhong BL, Luo W, Li HM, Zhang QQ, Liu XG, Li WT, Li Y. Knowledge, attitudes, and practices towards COVID-19 among Chinese residents during the rapid rise period of the COVID-19 outbreak: a quick online cross-sectional survey. Int J Biol Sci 2020; 16(10):1745-1752. doi:10.7150/ijbs.45221. Available from http://www.ijbs.com/v16p1745.htm

17. Almutairi, Khalid \&Helih, Eyad\& Moussa, Mahaman\&Boshaiqah, Ahmad \&Alajilan, Abdulrahman \&Vinluan, Jason. (2015). Awareness, Attitudes, and Practices Related to Coronavirus Pandemic Among Public in Saudi Arabia. Family \& community health. 38. 332-340. 10.1097/FCH.0000000000000082.

18. Lin, Y., Huang, L., Nie, S. et al. Knowledge, Attitudes and Practices (KAP) related to the Pandemic (H1N1) 2009 among Chinese General Population: a Telephone Survey. BMC Infect Dis 11, 128 (2011). https://doi.org/10.1186/1471-2334-11-128

19. Pascal Geldsetzer. Using rapid online surveys to assess perceptions during infectious disease outbreaks: a cross-sectional survey on Covid19 among the general public in the United States and United Kingdom. J Med Internet Res 2020;22(4):e18790.

20. Person B, Sy F, Holton K, Govert B, Liang A, National Center for Inectious Diseases SCOT. Fear and stigma: the epidemic within the SARS outbreak. Emerg Infect Dis. 2004;10:358-63

21. Tao N. An analysis on reasons of SARS-induced psychological panic among students. Journal of Anhui Institute of Education. 2003;21:78-9

22. IBM SPSS software. https://www.ibm.com/in-en/analytics/spss-statistics-software

23. Wikipedia. Timeline of the COVID-19 pandemic in India. Available on: https://en.wikipedia.org/wiki/Timeline_of_the_COVID-19_pandemic_in_India\#cite_note-253

24. Malaysian woman found coronavirus positive, first in Jharkhand". outlook india. 31 March 2020. Retrieved 18 May 2020.

25. Austrian K, Pinchoff J, Tidwell JB, White C, Abuya T, Kangwana B, et al. COVID-19 related knowledge, attitudes, practices and needs of households in informal settlements in Nairobi, Kenya. [Submitted]. Bull World Health Organ. E-pub: 6 April 2020. doi: http://dx.doi.org/10.2471/BLT.20.260281 
26. Li X, Xu S, Yu M, et al. Risk factors for severity and mortality in adult COVID-19 inpatients in Wuhan [published online ahead of print, 2020 Apr 12]. J Allergy Clin Immunol. 2020;S0091-6749(20)30495-4. doi:10.1016/j.jaci.2020.04.006

27. Yang J, Zheng Y, Gou X, et al. Prevalence of comorbidities and its effects in patients infected with SARSCoV-2: a systematic review and meta-analysis. Int $J$ Infect Dis. 2020;94:91-95. doi:10.1016/j.ijid.2020.03.017

28. Viceconte G, Petrosillo N. COVID-19 R0: Magic number or conundrum?. Infect Dis Rep. 2020;12(1):8516. Published 2020 Feb 24. doi:10.4081/idr.2020.8516

29. https://www.timesnownews.com/india/article/covid-19

30. https://www.opindia.com/2020/03/fake-hand-sanitiser-factory-busted-mumbai-haryana-coronavirus/

31. https://economictimes.indiatimes.com/news/politics-and-nation/government-of-india-has-asked-liquormanufacturers-to-make-alcohol-available-for-sanitiser/articleshow/74750486.

32. Mishra P., Bhadauria U.S., Dasar P.L., Kumar S., Lalani A., Sarkar P., Chauhan A., Godha S., Vyas S. Knowledge, attitude and anxiety towards pandemic flu a potential bio weapon among health professionals in Indore City. Przegl. Epidemiol. 2016;70:125-127. 41-5.

33. Nicola M, Alsafi Z, Sohrabi C, et al. The Socio-Economic Implications of the Coronavirus and COVID-19 Pandemic: A Review [published online ahead of print, 2020 Apr 16]. Int J Surg. 2020;S17439191(20)30316-2.

34. Ren SY, Gao RD, Chen YL. Fear can be more harmful than the severe acute respiratory syndrome coronavirus 2 in controlling the corona virus disease 2019 epidemic. World J Clin Cases. 2020;8(4):652-657. doi:10.12998/wjcc.v8.i4.652

35. Manuel Rojas, et al. Convalescent plasma in Covid-19: Possible mechanisms of action. Autoimmunity Reviews (in-press)

36. P. Venkatraman et al. Breakthrough of COVID-19 using radiotherapy treatment modalities. Radiotherapy and Oncology. 2020. 148, P225-226

37. Tobaiqy M, Qashqary M, Al-Dahery S, et al. Therapeutic Management of COVID-19 Patients: A systematic review [published online ahead of print, 2020 Apr 17]. 2020;100061.

38. https://www.mohfw.gov.in/pdf/AddressingSocialStigmaAssociatedwithCOVID19.pdf

AND https://www.who.int/who-documents-detail/a-guide-to-preventing-and-addressing-social-stigmaassociated-with-covid-19?

39. Tidwell J, Gopalakrishnan A, Lovelady S, Sheth E, Unni A, Wright R, et al. Effect of two complementary mass-scale media interventions on handwashing with soap among mothers. Journal of Health Communication. 2019:1-13. doi: doi: 10.1080/10810730.2019.1593554].

40. Jordan J, Yoeli E, Rand D. Don't get it or don't spread it? Comparing self-interested versus prosocially framed COVID-19 prevention messaging. PsyArXiv Preprints. 2020. doi:10.31234/osf.io/yuq7x.

41. Everett J, Colombatto C, Chituc V, Brady W, Crockett M. The effectiveness of moral messages on public health behavioral intentions during the COVID-19 pandemic. PsyArXiv Preprints. 2020. 
Table 1: Demographic details of the participants:

\begin{tabular}{|r|l|c|}
\hline S. No. & Variable & Frequency (\%) \\
\hline 1. & Age & \\
\hline & Upto 30 years & $2226(47.5)$ \\
\hline & 31 to 45 years & $1795(38.3)$ \\
\hline & 46 to 60 years & $556(11.9)$ \\
\hline & 60 and above & $44(0.9)$ \\
\hline & Not disclosed & $62(1.3)$ \\
\hline 2. & Gender & $3813(81.4)$ \\
\hline & Male & $850(18.1)$ \\
\hline & Female & $1(0.02)$ \\
\hline & Transgender & $16(0.3)$ \\
\hline & Prefer not to disclose & \\
\hline 3. & Education & $1626(34.7)$ \\
\hline & Above graduation & $2159(46.1)$ \\
\hline & Graduation & $487(10.3)$ \\
\hline & Senior Secondary & $264(5.6)$ \\
\hline & High School & $90(1.9)$ \\
\hline & Middle School & $57(1.2)$ \\
\hline & Primary and lower & \\
\hline 4. & Occupation & $741(15)$ \\
\hline & Unemployed & $1056(22)$ \\
\hline & Student & $393(8.3)$ \\
\hline & Self-employed & $1427(30)$ \\
\hline & Government employee & $574(12.2)$ \\
\hline & Private employee & $63(1.34)$ \\
\hline & Retired employee & \\
\hline & Others & $1473(30.6)$ \\
\hline $\mathbf{5 .}$ & Income & $877(18.7)$ \\
\hline & less than or equal to 10,000 score & $678(14.4)$ \\
\hline & $10,001-25,000$ score & $180(3.8)$ \\
\hline & 25,001 - 50,000 score & $1003(21.4)$ \\
\hline & $51,000-1,00,000$ score & \\
\hline & More than 1 lakh score & \\
\hline & Prefer not to disclose & \\
\hline & & \\
\hline
\end{tabular}


Table II: Knowledge regarding COVID-19

\begin{tabular}{|c|c|c|c|c|c|}
\hline $\begin{array}{l}\text { S. } \\
\text { No } \\
\cdot\end{array}$ & $\begin{array}{l}\text { Domains of } \\
\text { knowledge } \\
\text { assessment }\end{array}$ & Question & $\begin{array}{l}\text { Proportion of } \\
\text { individuals } \\
\text { with correct } \\
\text { responses }\end{array}$ & $\mathbf{N}$ & $\begin{array}{c}\text { Mean } \pm \\
\text { SD } \\
\text { (range) }\end{array}$ \\
\hline \multirow[t]{4}{*}{1.} & \multirow{4}{*}{$\begin{array}{l}\text { Clinical } \\
\text { aspects of } \\
\text { COVID-19 }\end{array}$} & $\begin{array}{l}\text { Knowledge regarding sypmptoms of } \\
\text { COVID-19 }\end{array}$ & 4507 (96.2) & \multirow{4}{*}{$\begin{array}{c}468 \\
3\end{array}$} & \multirow{4}{*}{$\begin{array}{c}3.18 \\
\pm 0.89 \\
(0.00- \\
04.00)\end{array}$} \\
\hline & & $\begin{array}{l}\text { People easily affected by COVID-19 } \\
\text { are }\end{array}$ & $3364(71.8)$ & & \\
\hline & & $\begin{array}{l}\text { How long can it take for COVID-19 } \\
\text { to appear after infection? }\end{array}$ & $3284(70.1)$ & & \\
\hline & & $\begin{array}{l}\text { Who should go to the COVID-19 } \\
\text { screening facility? }\end{array}$ & $3734(79.7)$ & & \\
\hline \multirow[t]{4}{*}{2.} & \multirow{4}{*}{$\begin{array}{l}\text { Spreadability } \\
\text { of COVID-19 } \\
\text { virus }\end{array}$} & $\begin{array}{l}\text { How does the COVID-19 virus } \\
\text { spread? }\end{array}$ & $3341(71.3)$ & \multirow{4}{*}{$\begin{array}{c}468 \\
3\end{array}$} & \multirow{4}{*}{$\begin{array}{l}3.09 \\
\pm 0.94 \\
(0.00- \\
04.00)\end{array}$} \\
\hline & & $\begin{array}{l}\text { Can a COVID-19 infected person } \\
\text { infect others even when symptoms } \\
\text { are not present? }\end{array}$ & 3394 (72.4) & & \\
\hline & & $\begin{array}{l}\text { How many meters distance } \\
\text { required from another person to } \\
\text { ensure safety from COVID-19 }\end{array}$ & 3543 (75.6) & & \\
\hline & & $\begin{array}{l}\text { What are effective ways to reduce the } \\
\text { spread of COVID-19? }\end{array}$ & 4191 (89.4) & & \\
\hline \multirow[t]{6}{*}{3.} & \multirow{6}{*}{$\begin{array}{l}\text { Prevention and } \\
\text { control of } \\
\text { COVID-19 }\end{array}$} & $\begin{array}{l}\text { How long should you wash your } \\
\text { hands with soap for protection from } \\
\text { COVID-19? }\end{array}$ & 4087 (87.2) & \multirow{6}{*}{$\begin{array}{c}468 \\
3\end{array}$} & \multirow{6}{*}{$\begin{array}{c}4.46 \\
\pm 1.08 \\
(0.00- \\
06.00)\end{array}$} \\
\hline & & $\begin{array}{l}\text { If you come in contact with someone } \\
\text { infected with COVID-19 virus, how } \\
\text { many days should you stay in } \\
\text { isolation? }\end{array}$ & 4278 (91.3) & & \\
\hline & & $\begin{array}{l}\text { Has the Jharkhand government made } \\
\text { it mandatory for COVID- } 19 \text { to wear } \\
\text { masks when going out for protection? }\end{array}$ & $3469(74.07)$ & & \\
\hline & & $\begin{array}{l}\text { What is the minimum appropriate } \\
\text { percentage of alcohol in hand } \\
\text { sanitizer? }\end{array}$ & 2681 (57.2) & & \\
\hline & & $\begin{array}{l}\text { Is COVID-19 vaccine } \\
\text { available? }\end{array}$ & 4401 (93.9) & & \\
\hline & & $\begin{array}{l}\text { Are national / Jharkhand helpline } \\
\text { numbers or emails dedicated for } \\
\text { COVID-19? }\end{array}$ & 4314 (92.1) & & \\
\hline 4. & \multicolumn{3}{|l|}{ Total knowledge } & 4683 & $\begin{array}{l}10.73 \pm 2.20 \\
(0.00- \\
14.00)\end{array}$ \\
\hline
\end{tabular}


Table III: Attitude against COVID-19

\begin{tabular}{|c|c|c|}
\hline S.No. & Question & Responses \\
\hline \multirow[t]{6}{*}{1.} & \multicolumn{2}{|c|}{ Do you agree that COVID-19 will finally be successfully controlled in India? } \\
\hline & Strongly disagree & $117(2.4)$ \\
\hline & Disagree & $150(3.2)$ \\
\hline & Neutral & $226(4.8)$ \\
\hline & Agree & $2081(44.4)$ \\
\hline & Strongly agree & $2109(45.3)$ \\
\hline \multirow[t]{5}{*}{2.} & \multicolumn{2}{|c|}{ How long do you think it will take to contain the COVID-19 outbreak in India? } \\
\hline & Minimum 1 month & $594(12.7)$ \\
\hline & Minimum 2 months & $1830(39.0)$ \\
\hline & Minimum 6 months & $1273(27.2)$ \\
\hline & Not sure & $989(21.1)$ \\
\hline \multirow[t]{6}{*}{3.} & \multicolumn{2}{|c|}{$\begin{array}{l}\text { Do you agree that nation-wide lockdown of } 21 \text { days is the best way to reduce the } \\
\text { spread of COVID-19 }\end{array}$} \\
\hline & Strongly disagree & $125(2.7)$ \\
\hline & Disagree & $143(3.1)$ \\
\hline & Neutral & $103(2.2)$ \\
\hline & Agree & $1956(41.8)$ \\
\hline & Strongly agree & $2356(50.3)$ \\
\hline \multirow[t]{4}{*}{4.} & \multicolumn{2}{|c|}{ How much your daily life been disturbed by COVID-19? } \\
\hline & Less affected & $2346(50.1)$ \\
\hline & Not affected & $532(11.4)$ \\
\hline & Disturbed & $1805(38.5)$ \\
\hline \multirow[t]{3}{*}{5.} & \multicolumn{2}{|c|}{ Do you worry about getting infected from COVID-19? } \\
\hline & Yes & $3115(66.5)$ \\
\hline & No & $1568(33.5)$ \\
\hline
\end{tabular}


Table IV: Practices regarding COVID-19

\begin{tabular}{|c|c|c|c|c|}
\hline S.No & Question & Responses & $\mathbf{N}$ & $\begin{array}{l}\text { Mean } \pm \text { SD } \\
\text { (range) }\end{array}$ \\
\hline \multirow[t]{3}{*}{1.} & \multicolumn{2}{|c|}{$\begin{array}{l}\text { In recent days, have you gone outside without any } \\
\text { compelling reason? }\end{array}$} & \multirow{23}{*}{4683} & \multirow{23}{*}{$\begin{array}{c}4.5298 \pm 0.69(0 \\
-5.00)\end{array}$} \\
\hline & Yes & $343(7.3)$ & & \\
\hline & No & $4340(92.7)$ & & \\
\hline 2. & Do you we & & & \\
\hline & Yes & $4576(97.7)$ & & \\
\hline & \begin{tabular}{|l} 
No \\
\end{tabular} & $107(2.3)$ & & \\
\hline \multirow[t]{6}{*}{3.} & \multicolumn{2}{|c|}{$\begin{array}{l}\text { Do you consciously make an effort to avoid touching the } \\
\text { eyes, nose, and mouth? }\end{array}$} & & \\
\hline & Always & 3165 (67.6) & & \\
\hline & Often & $898(19.2)$ & & \\
\hline & Sometimes & $419(8.9)$ & & \\
\hline & Rarely & $106(2.3)$ & & \\
\hline & Never & $95(2.0)$ & & \\
\hline \multirow[t]{3}{*}{4.} & \multicolumn{2}{|c|}{$\begin{array}{l}\text { Do you cover your nose and mouth when coughing or } \\
\text { sneezing? }\end{array}$} & & \\
\hline & Yes & 4627 (98.8) & & \\
\hline & No & $56(1.2)$ & & \\
\hline \multirow[t]{4}{*}{5.} & \multicolumn{2}{|c|}{$\begin{array}{l}\text { Have you downloaded the blue tooth based COVID-19 } \\
\text { tracker "ÄarogyaSetu App" }\end{array}$} & & \\
\hline & Yes & 3607 (77.0) & & \\
\hline & No & $828(17.7)$ & & \\
\hline & Not aware & $248(5.3)$ & & \\
\hline \multirow[t]{4}{*}{6.} & \multicolumn{2}{|c|}{$\begin{array}{l}\text { Do you verify news regarding COVID-19 before } \\
\text { forwarding on social media? }\end{array}$} & & \\
\hline & Yes & $4156(88.7)$ & & \\
\hline & No & $272(5.8)$ & & \\
\hline & Sometimes & $255(5.4)$ & & \\
\hline
\end{tabular}


Image I: Major concern among participants who are worried from COVID-19

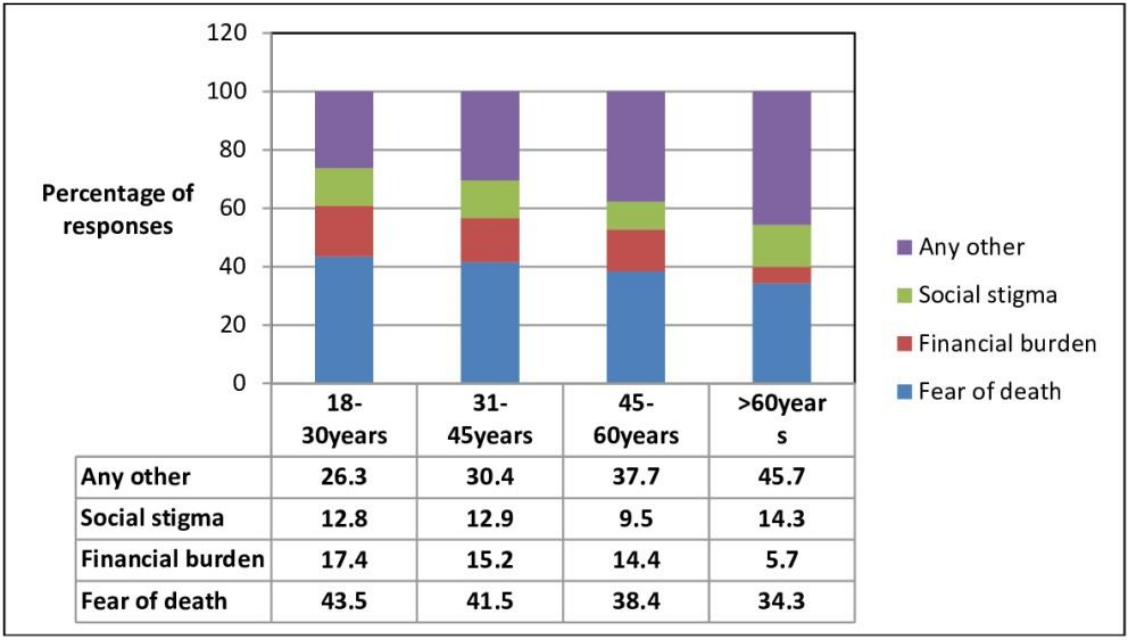

Image II: Source of information regarding COVID-19? (*multiple options could be marked for this question)

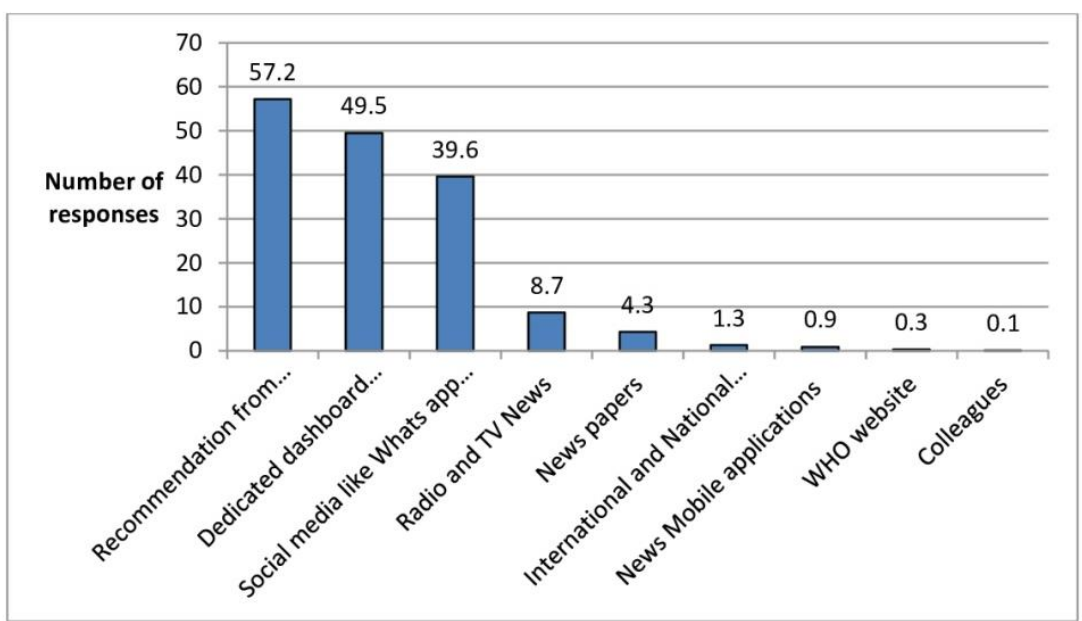


Table V: Association between different study variables

\begin{tabular}{|c|c|c|c|c|c|c|c|c|}
\hline \multirow{2}{*}{$\begin{array}{l}\text { Independent } \\
\text { variables }\end{array}$} & \multicolumn{8}{|c|}{ Dependent variables } \\
\hline & $\begin{array}{l}\text { Aware } \\
\text { n }(\%)\end{array}$ & $\begin{array}{l}\text { Unaware } \\
\mathbf{n}(\%)\end{array}$ & Total & $\begin{array}{l}\text { Chi } \\
\text { square } \\
\text { (p } \\
\text { value) }\end{array}$ & $\begin{array}{l}\text { Good } \\
\text { Practices } \\
\text { n }(\%)\end{array}$ & \begin{tabular}{|l|} 
Bad \\
practices \\
n $(\%)$
\end{tabular} & Total & $\begin{array}{l}\text { Chi square } \\
\text { (p value) }\end{array}$ \\
\hline \multicolumn{9}{|l|}{ Age } \\
\hline Upto 30 years & $\begin{array}{l}1968 \\
(88.4)\end{array}$ & $\begin{array}{c}258 \\
(11.6)\end{array}$ & 2226 & \multirow{4}{*}{$<0.0001$} & $\begin{array}{l}2189 \\
(98.3)\end{array}$ & $37(1.7)$ & 2226 & \multirow{4}{*}{0.061} \\
\hline 31 to 45 years & $\begin{array}{c}1707 \\
(95.1)\end{array}$ & $88(4.9)$ & 1795 & & $\begin{array}{l}1780 \\
(99.2)\end{array}$ & $15(0.8)$ & 1795 & \\
\hline 46 to 60 years & $\begin{array}{c}540 \\
(97.1)\end{array}$ & $16(2.9)$ & 556 & & $\begin{array}{c}545 \\
(98.0)\end{array}$ & $11(2.0)$ & 556 & \\
\hline 60 and above & $\begin{array}{c}41 \\
(93.2)\end{array}$ & $3(6.8)$ & 44 & & $\begin{array}{c}44 \\
(100.0)\end{array}$ & $00.0(.0)$ & 44 & \\
\hline \multicolumn{9}{|l|}{ Gender } \\
\hline Male & $\begin{array}{l}3513 \\
(92.1)\end{array}$ & $300(7.9)$ & 3813 & \multirow{2}{*}{$<0.0001$} & $\begin{array}{l}3766 \\
(98.8)\end{array}$ & $47(1.2)$ & 3813 & \multirow{2}{*}{$<0.0001$} \\
\hline Female & $\begin{array}{c}785 \\
(92.4)\end{array}$ & 65 (7.6) & 850 & & $\begin{array}{c}836 \\
(98.4)\end{array}$ & 14 (1.6) & 850 & \\
\hline \multicolumn{9}{|l|}{ Education } \\
\hline $\begin{array}{l}\text { Primary } \\
\text { school or less }\end{array}$ & $\begin{array}{c}44 \\
(77.2)\end{array}$ & $13(22.8)$ & 57 & \multirow{6}{*}{$<0.0001$} & $55(96.5)$ & $2(3.5)$ & 57 & \multirow{6}{*}{$<0.0001$} \\
\hline Middle school & $\begin{array}{c}73 \\
(81.1)\end{array}$ & 17 (18.9) & 90 & & $84(93.3)$ & $6(6.7)$ & 90 & \\
\hline High school & $\begin{array}{c}196 \\
(74.2)\end{array}$ & 68 (25.8) & 264 & & $\begin{array}{c}256 \\
(96.9)\end{array}$ & $8(3.1)$ & 264 & \\
\hline Intermediate & $\begin{array}{c}428 \\
(87.9)\end{array}$ & $59(12.1)$ & 487 & & $\begin{array}{c}482 \\
(98.9)\end{array}$ & $5(1.1)$ & 487 & \\
\hline Graduate & $\begin{array}{l}2017 \\
(93.4)\end{array}$ & $142(6.6)$ & 2159 & & $\begin{array}{l}2129 \\
(98.6)\end{array}$ & $30(1.4)$ & 2159 & \\
\hline $\begin{array}{l}\text { Above } \\
\text { graduation }\end{array}$ & $\begin{array}{c}1550 \\
(95.3)\end{array}$ & $76(4.7)$ & 1626 & & $\begin{array}{c}1611 \\
(99.1)\end{array}$ & $15(0.9)$ & 1626 & \\
\hline \multicolumn{9}{|c|}{ Monthly income } \\
\hline $\begin{array}{l}\text { less than or } \\
\text { equal to } \\
10,000\end{array}$ & $\begin{array}{c}1279 \\
(86.8)\end{array}$ & $\begin{array}{c}194 \\
(13.2)\end{array}$ & 1473 & \multirow{3}{*}{$<0.0001$} & $\begin{array}{c}1455 \\
(98.8)\end{array}$ & $18(1.2)$ & 1473 & \multirow{3}{*}{0.092} \\
\hline $\begin{array}{l}10,001- \\
25,000\end{array}$ & $\begin{array}{c}825 \\
(93.9)\end{array}$ & $53(6.1)$ & 878 & & $\begin{array}{c}868 \\
(98.9)\end{array}$ & $10(1.1)$ & 878 & \\
\hline $\begin{array}{l}25,001- \\
50,000\end{array}$ & $\begin{array}{c}659 \\
(97.2)\end{array}$ & $19(2.8)$ & 678 & & $\begin{array}{c}672 \\
(99.1)\end{array}$ & $6(0.9)$ & 678 & \\
\hline
\end{tabular}




\begin{tabular}{|l|c|c|c|c|c|c|c|c|}
\hline $\begin{array}{l}51,000- \\
1,00,000\end{array}$ & $\begin{array}{c}464 \\
(98.5)\end{array}$ & $7(1.5)$ & 471 & & $\begin{array}{c}466 \\
(98.9)\end{array}$ & $5(1.1)$ & 471 & \\
\cline { 1 - 2 } $\begin{array}{l}\text { More than one } \\
\text { lakh }\end{array}$ & $\begin{array}{c}175 \\
(97.2)\end{array}$ & $5(2.8)$ & 180 & & $\begin{array}{c}175 \\
(97.2)\end{array}$ & $5(2.8)$ & 180 & \\
\hline
\end{tabular}

Table VI: Association between knowledge and practices of participants

\begin{tabular}{|l|c|c|c|l|}
\hline Knowledge & Good practices (\%) & Bad Practices (\%) & Total awareness (\%) & $\begin{array}{l}\text { Chi } \\
\text { square (p } \\
\text { value) }\end{array}$ \\
\cline { 1 - 4 } Aware & $4263(99.0)$ & $45(01.0)$ & $4308(92.0)$ & \multirow{2}{*}{$<0.0001$} \\
\cline { 1 - 2 } Unaware & $354(94.4)$ & $21(5.6)$ & $375(08.0)$ & \\
\cline { 1 - 4 } Total practice & $4617(98.6)$ & $66(1.4)$ & $4683(100.0)$ & \\
\hline
\end{tabular}


Figures

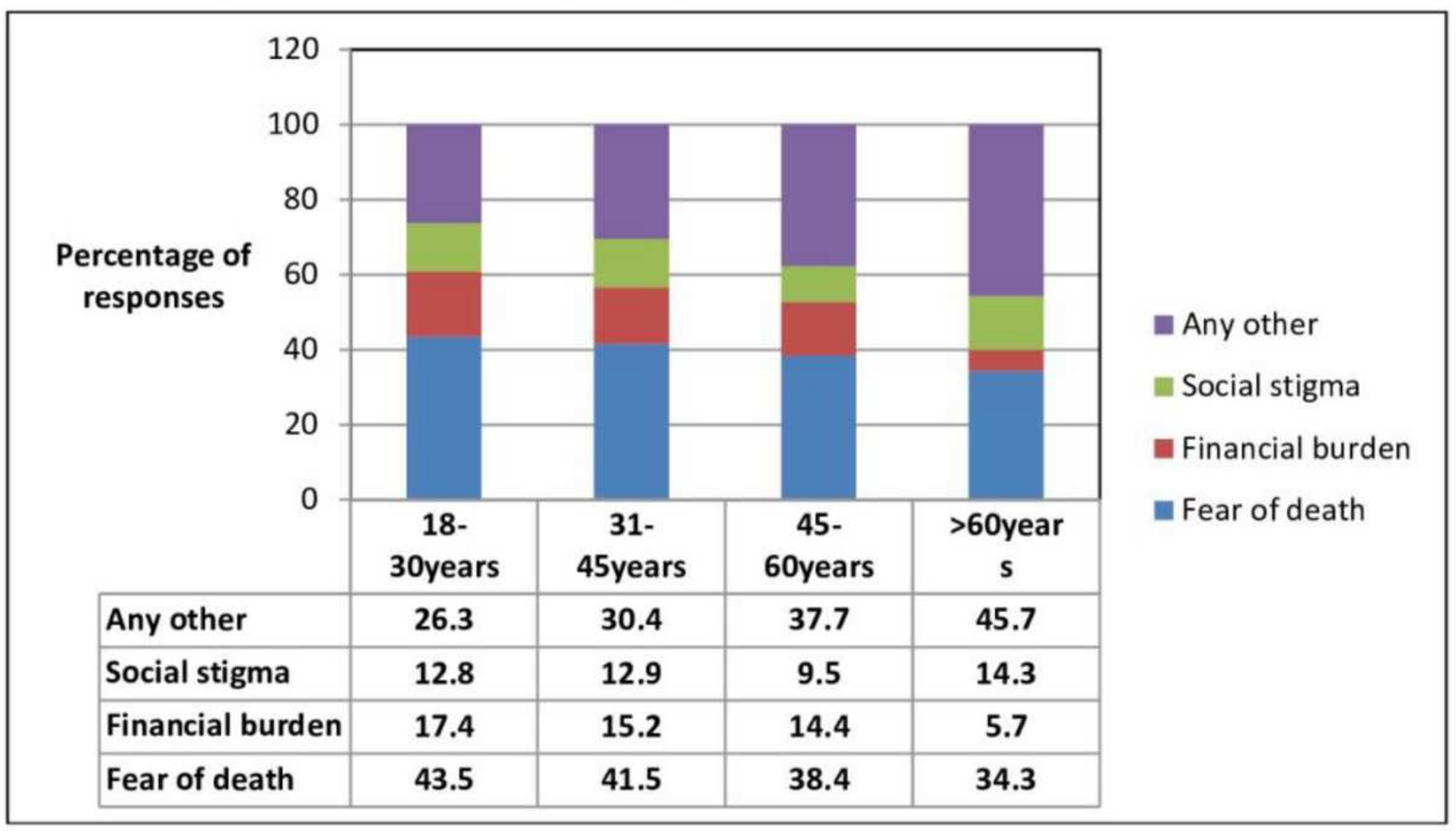

Figure 1

Major concern among participants who are worried from COVID-19 


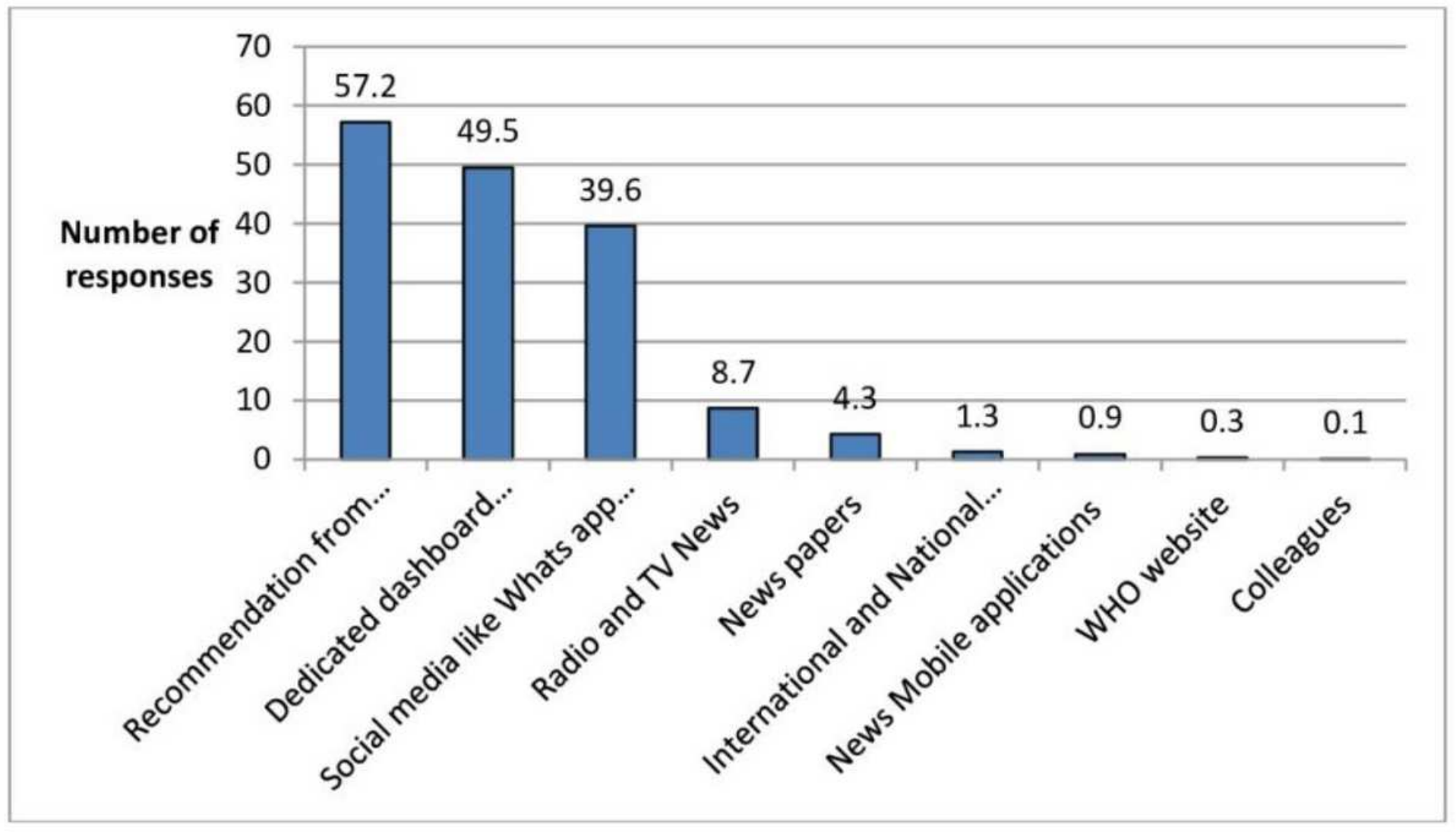

Figure 2

Source of information regarding COVID-19? (*multiple options could be marked for this question) 